\title{
Birds extend their ranges northwards
}

W have analysed the breeding distributions of British birds over a 20-year period. After controlling for overall population expansions and retractions, we find that the northern margins of many species have moved further north by an average of $18.9 \mathrm{~km}$ during this time. This general northward shift took place during a period of climatic warming, which we propose might be causally involved.

Butterfly species are moving northwards in Europe ${ }^{1}$, probably in response to climate warming 2,3 . Studies of other species that show range expansions at one margin closer to the pole or towards a higher elevation ${ }^{4-6}$ can be difficult to interpret because changes at single margins might be part of overall population expansions, without any true bias from elevation or latitude ${ }^{7,8}$. Here we control for this effect, using data on British birds, and still find that northern margins have expanded northwards.

We used data from two atlases of breeding birds compiled for Great Britain, based on a $100-\mathrm{km}^{2}$ grid and encompassing the periods 1968-72 (ref. 9) and 1988-91 (ref. 10). Overall increases in distribution size, whatever the cause, would be expected to cause species restricted to the south of Britain (for example, Cettia cetti) ${ }^{10}$ to move northwards at their northernmost boundary, and species restricted to the north (such as Mergus merganser) ${ }^{10}$ to move southwards. In contrast, a general decline in a species

Figure 1 Change in the range margins of bird species (defined as the mean distance northwards of the ten most marginal records in 1988-91 minus the mean of the ten most marginal records in 1968-72; positive values indicate a move northwards, and negative values a move southwards) plotted against changes in status $\left(\log _{10}\right.$ of the numbers of $100-\mathrm{km}^{2}$ grid cells occupied in 1988-91 compared with 1968-72). Only $100-\mathrm{km}^{2}$ grid cells mapped in both atlases were analysed. a, Plot for 59 southerly species for which the mean location of the occupied $100 \mathrm{~km}^{2}$ was south of the mean location of all $100-\mathrm{km}^{2}$ cells in Great Britain; the northern margin was analysed. The equation for the regression line is $x=18.87 \mathrm{~km}$ (s.e.m. 6.52, $P<0.0054)+255.63 \quad$ (s.e.m 47.47, $P<0.0001$ )y; $r^{2}=0.337$. b, Plot for 42 northerly species for which the mean location of the occupied $100 \mathrm{~km}^{2}$ was north of the mean location of all $100-\mathrm{km}^{2}$ cells; the southern margin was analysed. The equation of the regression line is $x=-4.48 \mathrm{~km}$ (s.e.m. 8.96, $P=0.6200$ ) - 183.45 (s.e.m. 43.07, $P<0.0001$ )y; $r^{2}=0.312$. The following categories of species were excluded: those occupying $<20$ cells, to avoid counting southernmost as well as northernmost records for the rarest species; ubiquitous species occupying $>2,000$ out of the 2,280 cells available; recently introduced species; species for which grid cells were moved or omitted on published maps. A larger sample of 95 southerly species that included species occupying 2,000-2,280 grid cells was also significant (intercept, $13.33 \mathrm{~km}$ (northwards); $P=0.0016$ ), but this underestimates the true shift because species occupying 2,000-2,280 cells had less opportunity to colonize new grid cells northwards. The result for northerly species was unaffected by the inclusion of two extra species occupying 2,000-2,280 cells (intercept, $-3.90 \mathrm{~km}$ (southwards), $P=0.6505$ ). would be expected to cause northern species (Tetrao tetrix, for instance $)^{10}$ to retract northwards, and southern species (such as Streptopelia turtur) ${ }^{10}$ to retract southwards, towards their cores ${ }^{8}$. These patterns arise because the most marginal records are likely to be further from the distributional core in a period with more $100-\mathrm{km}^{2}$-grid records of a species. They do not reflect any systematic shift north or south.

For terrestrial or freshwater bird species with southerly distributions in Britain, we recorded the mean location of the ten most northerly grid squares with breeding in 1968-72 (ref. 9) and 1988-91 (ref. 10). As expected, the northern margins of most southerly species that increased in numbers of squares over the 20-year period shifted northwards, and the northern margins of many southerly species that declined overall shifted southwards (Fig. 1a). The $x=0$ intercept in Fig. 1a shows the mean shift in range for species with no overall change in the number of grid squares occupied: a northward shift of $18.9 \mathrm{~km}(P=0.0054)$. The left-hand point in Fig. 1a could have affected the result, so we re-analysed the relation by omitting this point and then leaving out the two left-hand points. These produced intercept values of 18.3 $(P=0.0064)$ and $19.4 \quad(P=0.0033) \mathrm{km}$ shifts to the north.

For northerly species, we recorded the mean locations of the ten southernmost

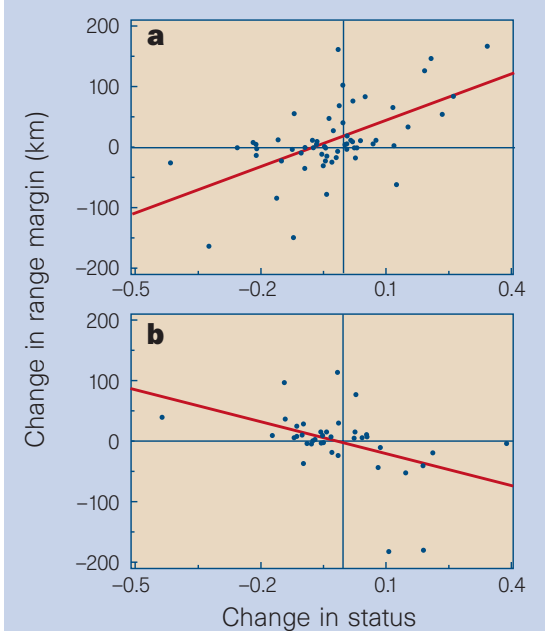

grid squares with breeding in 1968-72 (ref. 9) and 1988-91 (ref. 10). The southern margins of northerly species that increased in numbers of squares over the 20-year period generally shifted southwards, whereas the southern margins of most species that declined shifted northwards (Fig. 1b). For these species, there has been no systematic shift northwards or southwards (intercept, $4.5 \mathrm{~km}$ south; $P=0.62$ ).

Many factors might have caused the distributions of particular species to change in individualistic ways. Nevertheless, after taking account of changes in the numbers of grid squares occupied, we estimate that the northern margins of southerly species have moved north by an average of $18.9 \mathrm{~km}$ in 20 years. The most parsimonious explanation is climate, given that: (1) recent changes in the timing ${ }^{11}$ and success ${ }^{12}$ of bird reproduction are associated with warmer spring conditions; (2) the overall spatial distribution of bird diversity in Britain is correlated with that of temperature ${ }^{13} ;$ (3) summer temperature was a significant predictor of the breeding distribution of 87 of $194(45 \%)$ terrestrial and freshwater bird species (J. J. L., J. J. D. Greenwood and J. R. G. Turner, unpublished observations); and (4) the shifts coincided with a period of climate warming, ${ }^{2,3}$. In contrast, the southern margins of northerly species have not shifted consistently. This parallels the result obtained for European butterflies, for which the northern margins have expanded more than the southern margins have retracted ${ }^{1}$. Cool margins of temperate species might be more immediately responsive than warm margins to the direct effects of thermal variation; warm margins might respond more to rainfall, species interactions or longer-term climate-related changes in the vegetation.

Chris D. Thomas, Jack J. Lennon

Centre for Biodiversity and Conservation,

School of Biology, University of Leeds,

Leeds LS2 9JT, UK

e-mail:c.d.thomas@leeds.ac.uk

. Parmesan, C. et al. Nature (in the press).

2. Easterling, D. R. et al. Science 277, 364-367 (1997).

. Conway, D. Prog. Phys. Geogr. 22, 350-374 (1998).

Taylor, R. H. \& Wilson, P. R. N. Z. J. Ecol. 14, 25-29 (1990).

5. Grabherr, G., Gottfried, M. \& Pauli, H. Nature 369, 448 (1994).

6. Epstein, P. R. et al. Bull. Am. Meteorol. Soc. 79, 409-417 (1998).

Parmesan, C. Nature 382, 765-766 (1996)

8. Melham, D. W. Ecol. Appl. 7, 614-624 (1997).

9. Sharrock, J. T. R. The Atlas of Breeding Birds in Britain and Ireland (Poyser, Berkhamsted, 1976).

10. Gibbons, D. W., Reid, J. B. \& Chapman, R. A. The New Atlas of Breeding Birds in Britain and Ireland: 1988-1991 (Poyser, London, 1993).

11.Crick, H. Q. P., Dudley, C., Glue, D. E. \& Thomson, D. L. Nature 388, 526 (1997).

12. Visser, M. E., van Noordwijk, A. J., Tinbergen, J. M. \& Lessells, C. M. Proc. R. Soc. Lond, B 265, 1867-1870 (1998).

13. Turner, J. R. G., Lennon, J. J. \& Lawrenson, J. A. Nature 335, 539-541 (1988). 